\title{
Symptomatic pulmonary restriction secondary to diaphragmatic eventration and megacolon in adult
}

\author{
Shinban Liu, George Ferzli
}

General Surgery, NYU Langone Medical Center, Brooklyn, New York, USA

Correspondence to Dr Shinban Liu, shinban.liu@nyumc.org

Accepted 17 July 2018

\section{DESCRIPTION}

A 70-year-old woman with a medical history significant for toxic megacolon secondary to Clostridium difficile infection treated 40 years prior with partial colectomy and known diaphragmatic eventration presents with a 3-day history of progressive shortness of breath and dyspnoea on exertion. The patient had never previously been symptomatic nor suffered blunt trauma and had a strong personal conviction to avoid surgery. CT imaging revealed a massive left diaphragmatic displacement containing spleen, stomach and colon with mediastinal shift, compression of the left lung and a pericardial effusion (figure 1). Due to persistent tachycardia and presence of pericardial effusion on CT, a transthoracic echocardiogram was obtained, which demonstrated a large pericardial effusion concerning for tamponade physiology. The patient developed supraventricular tachycardia for which cardiology was consulted and two doses of adenosine were administered with resolution. The patient was upgraded to surgical intensive care and taken to the operating room for a subxiphoid pericardial window with drainage of $500 \mathrm{cc}$ of straw-coloured fluid by cardiothoracic surgery. She continued to improve clinically and was optimised with nutrition supplementation and physical therapy. Once stable, she was discharged to cardiac rehabilitation. After physiological optimisation, she returned to the hospital for an elective laparoscopic colectomy with primary anastomosis and diaphragmatic plication.

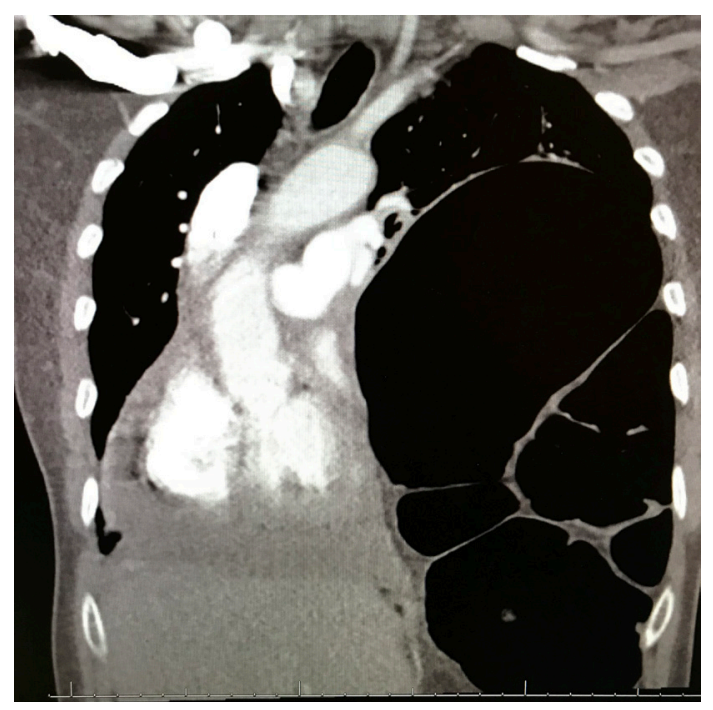

Figure $1 \mathrm{CT}$ of the abdomen and pelvis with massive left diaphragmatic displacement causing mediastinal shift and compression of the left lung.
A periumbilical Hasson port was used to enter the abdomen with additional ports placed in the right lower quadrant and suprapubic region. The efferent and afferent limbs of the involved colon were identified and resected using a laparoscopic stapling device. The remaining colon appeared viable and grossly normal, so a side-to-side anastomosis was performed with the stapling device. The diaphragmatic muscle was then plicated with non-absorbable polyester suture in a running-locked technique. Her postoperative course was unremarkable with postoperative imaging confirming significant improvement of her left lung space and clinical resolution of her respiratory symptoms.

Diaphragmatic eventration is a rare anomaly that occurs when part of the diaphragmatic muscle is replaced by connective tissue. This condition can be congenital from the failure of muscularisation in utero or acquired from phrenic nerve injury. Unlike a diaphragmatic hernia, there are no defects in the diaphragm, and there are normal muscular insertions to the costal margins. The majority of adult patients are asymptomatic; however, in rare cases, there can be associated dyspnoea, chest pain, dyspepsia, recurrent pneumonia and cardiac abnormalities. ${ }^{1}$ Diagnosis is based on plain radiographs that demonstrate an elevated dome of the hemidiaphragm. If asymptomatic, no further evaluation or treatment is necessary. Pulmonary function tests may be performed if there is dyspnoea or when differentiating between eventration and unilateral diaphragm paralysis. Intrathoracic approaches via thoracotomy or video-assisted thoracotomy have been described, in addition to intra-abdominal repair if surgery is required. Eventration is most commonly corrected with diaphragmatic plication; however, the insertion of prostheses or excision and suture have also been proposed. ${ }^{2}$

\section{Learning points}

Diaphragmatic eventration occurs from the progressive distention of the diaphragmatic muscle secondary to the replacement of muscle by connective tissue.

- Diaphragmatic eventration is rarely symptomatic in adults but may cause respiratory and cardiac complications.

- Diaphragmatic eventration can be repaired through intrathoracic or intra-abdominal approaches with plication, excision and primary repair, or prosthetic mesh insertion. 
Contributors SL and GF were equal contributors to the investigation and editing of this case report.

Funding The authors have not declared a specific grant for this research from any funding agency in the public, commercial or not-for-profit sectors.

Competing interests None declared.

Patient consent Obtained.
Provenance and peer review Not commissioned; externally peer reviewed.

\section{REFERENCES}

1 Mouroux J, Venissac N, Leo F, et al. Surgical treatment of diaphragmatic eventration using video-assisted thoracic surgery: a prospective study. Ann Thorac Surg 2005;79:308-12.

2 Graham DR, Kaplan D, Evans CC, et al. Diaphragmatic plication for unilateral diaphragmatic paralysis: a 10-year experience. Ann Thorac Surg 1990;49:248-52.

Copyright 2018 BMJ Publishing Group. All rights reserved. For permission to reuse any of this content visit http://group.bmj.com/group/rights-licensing/permissions.

BMJ Case Report Fellows may re-use this article for personal use and teaching without any further permission.

Become a Fellow of BMJ Case Reports today and you can:

- Submit as many cases as you like

- Enjoy fast sympathetic peer review and rapid publication of accepted articles

- Access all the published articles

- Re-use any of the published material for personal use and teaching without further permission

For information on Institutional Fellowships contact consortiasales@bmjgroup.com

Visit casereports.bmj.com for more articles like this and to become a Fellow 